\title{
PENDAMPINGAN BACA TULIS AL-QUR'AN TKA/TPA Al-IKHLAS
}

\author{
RATNASARI \\ 9173770410258 \\ ratna.sarhyi@gmail.com
}

1. Bentuk Kegiatan

> Mengaji Bersama Santri TKA/TPA Al-ikhlas.

2. Lokasi

$>$ Posko KKLP dusun palloli desa Bontocini kecamatan rumbia.

3. Hari/Tanggal dan Waktu

> Selasa, 10 November 2020 pukul 18:20 - 18:40. Kamis, 12 November 2020 pukul 18:25 - 18:50.

4. Peserta yang Dilibatkan

> Santri TKA/TPA Al-Ikhlas

> Mahasiswa KKLP YAPTI Jeneponto

5. Alasan diadakannya

> Alasan diadakan pembimbingan baca tulis Qur'an kepada anak santri adalah karena melihat antusias santri dalam kegiatan belajar mengaji ini sangat besar sehingga kami berinisiatif untuk mendapingi santri dalam mengajarkan serta memperbaiki makhroj Huruf dan tajwidnya.

6. Tujuan dan Manfaat

$>$ Tujuan kegiatan ini adalah untuk mendampingi serta mengajarkan pelafalan huruf hijaiyah yang benar.

$>$ Manfaatnya yaitu santri bisa melafalkan huruf dengan baik dan benar.

7. Deskripsi Kegiatan

> Kegiatan ini dilaksanakan dengan maksud untuk memenuhi permintaan anak-anak di desa Bontocini. Kegiatan ini dilaksanakan di posko KKLP. 